\title{
Analysis of the Lebanese oil and gas exploration in the Mediterranean Sea: An overview and analysis of offshore platforms
}

\author{
Mohamad Khaled Abed Elrahim ${ }^{*}$, Moath Al Husban ${ }^{1}$ \\ ${ }^{1 *}$ Near East University/Faculty of Civil and Environmental Engineering/Nicosia, Mersin10, Turkey
}

\section{ARTICLE INFO}

\section{ARTICLE HISTORY:}

Received: 27 June 2020

Revised: 4 November 2020

Accepted: 12 December 2020

Published: 31 January 2021

\section{KEYWORDS:}

Offshore structures, Lebanese waters at sea, exploration, oil and natural gas

\section{A B S TR AC T}

Offshore structures are used around the world for many functions, and these structures vary according to the depth of the water, the depth of water and environmental conditions are the main factors that determine the type of platform and method of drilling, appropriate planning, manufacturing, transportation, installation, and start-up. At the beginning of the twentieth century, oil and natural gas were discovered in the Middle East, specifically in the Lebanese basin. This discovery opened the door for Lebanon and entered the club of oil states. This paper is a study and analysis of blocks No. 4 and No. 9 that may contain the largest amount of oil and natural gas in addition to studying and analysing the types of marine installations (fixed and movable) and provide the best suggestions for the type suitable platform for the process of extracting oil and natural gas from the Sea of Lebanon according to the depth of water and factors Natural. The option of a drillship for drilling is the most appropriate option, given the lack of sufficient information about the nature of the soil in the Lebanese Sea. The drillship is considered an optimal solution given for ease of movement and in the absence of oil, the cost is much lower than the installation of fixed platforms. Semisubmersible rig for drilling and Tension Leg Platform or Semisubmersible Platform as well as Subsea System for oil/gas extraction are good alternatives to be employed in the Lebanese oil/gas fields.

\section{INTRODUCTION}

1930 was the beginning of the journey to search for oil in Lebanon, where the French geologist Louis Dubertre organized the geological map of Lebanon. In 1972, Ziyad Baydoun, Head of the Geology Department at the American University of Beirut, confirmed that there are more than 2000 meters of marine layers where oil and gas can be found, and he affirmed that the reserves are abundant in northern Lebanon. This research did not receive the attention required until 2010 when the American company Noble Angry conducted a 3D seismic survey and identified a huge gas field called "Leviathan" in the Mediterranean. It is estimated that this field contains 450 billion cubic meters of gas (Skiple et al., 2012).

Offshore platforms represent a major challenge for the design engineer, these platforms must operate safely for not less than 25 years and more depending on existing conditions, they are subject to severe conditions where this design must withstand the loads caused by waves, hurricanes, winds and strong currents, Offshore platforms are one of the largest structures that a person has made, they are either steel or concrete structures or a combination of the two, there are many types each of which is used based on the depth of the water, the mission of offshore platforms is to extract oil and gas from the sea and to separate them from the water and then transport them to shore via pipelines or via ships.

In this paper Block No. 4 and No. 9 have been analysed. The depth of water in Block No. 4 and No. 9 is between 686 meters to 1845 meters (Nader, 2011).

\section{METHODOLOGY}

The methodology analyses these blocks No. 4 and No. 9 in the Lebanon Sea, the depth of both blocks in addition to 
providing appropriate suggestions for the process of extracting oil and natural gas from the Lebanese Sea.

\subsection{Available data of block No. 4 and No. 9}

As showing in Fig. 3, block No. 4 is located opposite the centre of Lebanon (Beirut), its area is estimated at $1911 \mathrm{~km}^{2}$. It is located at a distance of $30 \mathrm{~km}$ from the beach at a depth between 1,400 to 1,800 meters, it is a rocky well that stretches over the Mediterranean Sea, more than a thousand meters from the rest of the wells in Lebanon. The block was divided into three wells, each containing approximately 110-140 billion cubic meters of natural gas. Block No. 9 located in the south of Lebanon (Saida) with an area about $1742 \mathrm{~km}^{2}$ with a water depth ranging between 1,400 to 1,800 meters (Total, 2017), Fig. 1 illustrated the location of both blocks.

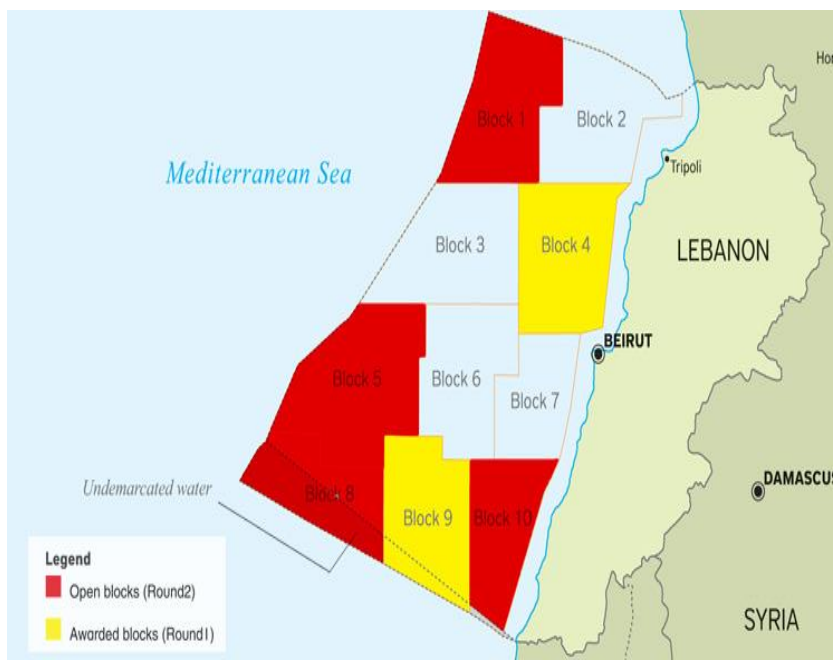

Fig.1. Location of both blocks No. 4 and No. 9 (Lebanon opportunities, 2017)

It is very important when designing offshore structures to take into account the study of the soil. The task of the soil is to withstand the pressure and the large movement of the marine platform, mobile or fixed. (Sadeghi, 2001).

\subsection{Structural analysis}

The structural analysis must include all major members of the attachments and major equipment. (American Petroleum Institute (API), 1996).

Often the marine structures supported by piles contains several parts, which are the main deck, the cellar deck, and the subcellar deck and a helideck (Sadeghi, 1989). Structural models' files consist of:

- The type of analysis, the mudline elevation and water depth,

- Member sizes,

- Joints definition,
- Soil data (i.e., mudmat bearing capacity, pile groups, TZ, P-Y, Q-Z curve points),

- Plate groups,

- Joint coordinates,

- Marine growth input,

- Inertia and mass coefficients (CD and CM) input,

- Distributed load surface areas,

- Wind areas,

- Anode weights and locations (Sadeghi, 2008).

Offshore platforms analysis should include equipment weights, maximum live load (distributed loads), and dead loads in addition to taking into account environmental and wind loads (EIA, 2013).

\subsection{Software used in the design of the platform}

To perform a structural analysis of platforms, the following software may be used:

- SACS, FASTRUDL, MARCS, OSCAR, StruCAD or SESAM for structural analysis,

- Maxsurf, Hydromax, Seamoor for hydrodynamics calculations,

- GRLWEAP, PDA, CAPWAP for pile analyses (Sadeghi, 2004).

\section{TYPES OF OFFSHORE PLATFORM}

In general, there are two types of offshore platforms: fixed offshore drilling platforms and movable offshore drilling platforms, and each of them contains many types, and the type of offshore platform is chosen based on the depth of water and oil and natural gas fields as shown in Figs. 2 and 3 (Salameh et al 2020).

It can be said that the platform in general consists of two main parts, which are the drilling machine and its task of exploration and drilling to reach the oil and natural gas fields and extract them, while the second section is the upper section which is above the water and its task is to manage the work of the drilling rig, separate the oil and natural gas and transfer them to land Through a network of pipes or through the use of ship (Sadeghi, 2007).

\subsection{Types of fixed offshore drilling platforms}

\subsubsection{Jacket platform}

This type of platform is used in water that is no more than 500 meters deep and this type can be installed directly on the bottom of the water, this platform consists of jackets, decks and piles. 


\subsubsection{Compliant towers platform}

This platform is used in a water depth not exceeding 900 meters. The platform consists of narrow, flexible towers and foundations that support the traditional surface of the drilling and production process.

\subsubsection{SeaStar platform}

The platform consists of a floating device that fills with water when starting the drilling process to increase the stability of the platform against the movement of water and wind. Also, this platform includes a tension leg system that is long strings that extend from the seabed to the floating platform, this platform works at a depth of more than 1000 meters.

\subsubsection{Floating production system}

This platform follows the floating production system, which is semi-submersible platforms where the platform can be kept in place through its own and very heavy anchors. This platform can operate at a depth of 1800 meters.

\subsubsection{Tension leg platform}

It is a larger version of the SeaStar platform, it is long and flexible. This platform operates at a depth of greater than 300 meters.

\subsubsection{Subsea system}

They are subsea production systems. They are wells on the seabed that extract oil and gas from the seabed and then transport it through a pipeline network to a platform located above the sea. This platform cannot drill and operate at a depth of 2200 meters.

\subsubsection{Spar platform}

It is the largest marine platform used. The platform consists of a large cylinder that does not reach the seabed. It is attached to the bottom with chains and cables. The cylinder's mission is to stabilize the platform in the water. This platform works at a depth of 3000 meters.

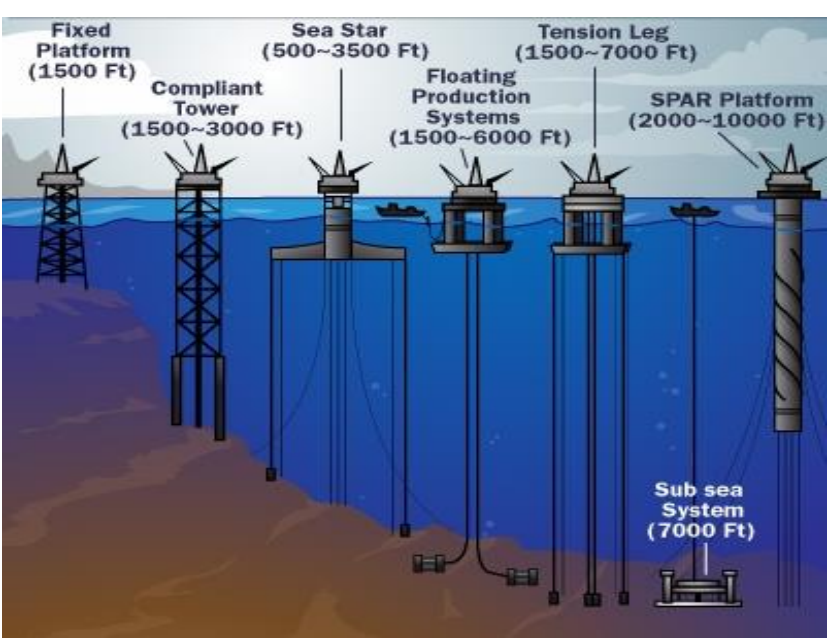

Fig. 2. Types of fixed offshore drilling platforms (How Offshore Drilling Works, 2020)

\subsection{Types of movable offshore drilling platforms}

\subsubsection{Jack-up platform}

Jack up is a movable offshore platform. It has three or four legs, the platform is moved to the drilling site and the legs are lowered to the seabed and operate at a depth of 150 meters.

\subsubsection{Semisubmersible platform}

This platform has a floating drilling rig consisting of columns and pontoons. The pontoons are flooded in water until they reach the specified depth, they are installed. By huge anchors of up to ten tons each, this platform can operate at a depth of 3000 meters.

\subsubsection{Drillship}

It is a ship designed for drilling that contains a hole called the "moon pool" which allows the drill string to travel from the ship to the seabed. This type of platform uses dynamic positioning systems in addition to motors capable of moving the ship in any direction to ensure that the ship is at all times located above the drilling area. It can operate a depth of 3650 meters. 
DOI: https://doi.org/10.47346/ijaesa.v2i1.60

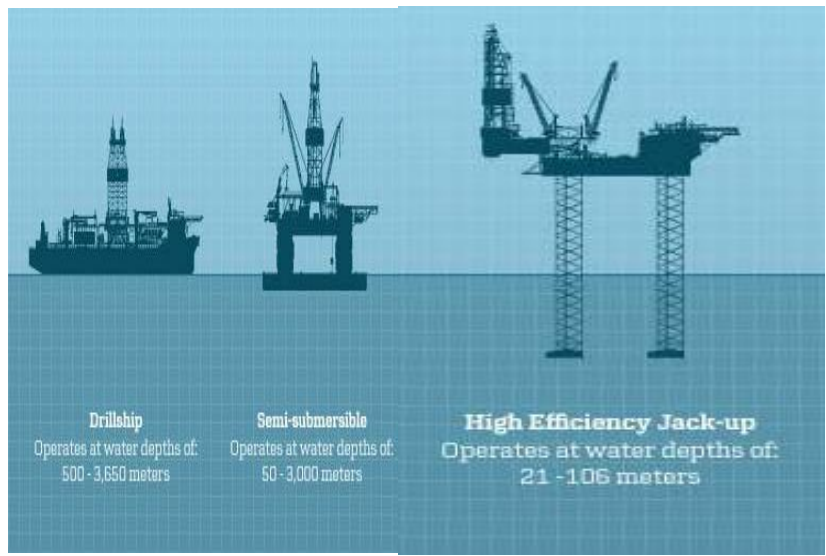

Fig. 3. Types of moveable offshore platforms (How Offshore Drilling Works, 2020)

\section{DISCUSSIONS}

The Lebanese state agreed with the French company Total for exploration and extraction of oil and natural gas present in Lebanese waters.

Total has chosen the drillship for the process of extracting the oil, as the drillship is able to patrol to a depth approx. $3650 \mathrm{~m}$ which is more than the depth of the oil wells located in the Lebanese sea.

Many platforms can be chosen for drilling, but the selection of the ferry is the most appropriate, due to several reasons, including that this drilling process can be said to be the first of its kind in addition to that it is not possible to confirm the presence of oil and natural gas in the Lebanese Sea and here the drillship is the most appropriate for its ease of movement in contrast to the platforms Fixed.

Since the depth of water in Block No. 4 and No. 9 in Lebanon waters varies between 686 meters to 1845 meters and the platforms/rigs types are chosen mainly due to the waterdepth considerations in which the oil/gas fields are situated, and due to the deck equipment necessary to perform its service, the following solutions are provided for the Lebanon oil/gas fields considering the environmental conditions and waterdepths.

Since the semisubmersible platforms/rigs can be used in the waterdepths up to 1800 meters, and the Tension Leg Platforms are used in waterdepths greater than 300 meters, Semisubmersible rig for drilling and Tension Leg Platform or Semisubmersible Platform as well as Subsea System for oil/gas extraction are good alternatives to be employed in the Lebanese oil/gas fields.

\section{CONCLUSIONS}

The choice of platform type depends on analysing the depth of the water in the first place in addition to the natural factors and the type of equipment that will be used in the process of extracting oil and natural gas.

The option of a drillship for drilling is the most appropriate option, given the lack of sufficient information about the nature of the soil in the Lebanese Sea. In addition, one hundred per cent of the existence of oil and gas wells cannot be assured, because this is the first time that Lebanon deals with the extraction of oil and gas, therefore the drillship is considered an optimal solution as a result of its easy movement and in the absence of oil, the cost is much lower than the installation of fixed platforms.

Since the semisubmersible platforms/rigs can be used in the waterdepths up to 1800 meters, and the Tension Leg Platforms are used in waterdepths greater than 300 meters, Semisubmersible rig for drilling and Tension Leg Platform or Semisubmersible Platform as well as Subsea System for oil/gas extraction are good alternatives to be employed in the Lebanese oil/gas fields.

\section{CONFLICT OF INTEREST STATEMENT}

The authors declare that there is no conflict of interest.

\section{REFERENCE}

[1] Al Abdalla, A., Barrier, E., Matar, A., \& Muller, C. (2010). Late Cretaceous to Cenozoic tectonic evolution of the NW Arabian platform in NW Syria. Geological Society, London, Special Publications, 341(1), 305327.

https://doi.org/10.1144/sp341.15

[2] American Petroleum Institute, (1996). Recommended Practice for Planning, Designing and Constructing Fixed Offshore Platforms - Working Stress Design (RP2A 20th edition, and Supplement 1).

[3] Lamb, R. (2020). How Offshore Drilling Works. Howstuffworks.

https://science.howstuffworks.com/environmental/ene rgy/offshore-drilling

[4] Mefleh, A., \& Khraibani, Z. (2020). Oil rig protection against wind and wave in Lebanon. Communications in Statistics: Case Studies, Data Analysis and Applications, 6(2), 191-214.

https://doi.org/10.1080/23737484.2020.1752847

[5] Nader, F. H. (2011). The petroleum prospectivity of Lebanon: an overview. Journal of Petroleum Geology, 34(2), 135-156. https://doi.org/10.1111/j.1747-5457.2011.00498.x

[6] Nader, F. H., Inati, L., Ghalayini, R., Hawie, N., \& Bou Daher, S. (2018). Key geological characteristics of the Saida-Tyr Platform along the eastern margin of the Levant Basin, offshore Lebanon: implications for hydrocarbon exploration. Oil \& Gas Science and 
Technology - Revue d'IFP Energies Nouvelles, 73, 50. https://doi.org/10.2516/ogst/2018045

[7] Sadeghi, K. (2008). Significant Guidance for Design and Construction of Marine and Offshore Structures, GAU J. Soc. \& Appl. Sci., 4(7), 67-92.

[8] Sadeghi, K. (2007)._An Overview of Design, Analysis, Construction and Installation of Offshore Petroleum Platforms Suitable for Cyprus Oil/Gas Fields, GAU J. Soc. \& Appl. Sci., 2(4), 1-16.

[9] Sadeghi, K. (2004). An Analytical Approach to Predict Downtime in Caspian Sea for Installation Operations. 6th International Conference on Ports, Coasts and Marine Structures (ICOPMAS 2004), Tehran, Iran.

[10] Sadeghi, K. (2001). Coasts, Ports and Offshore Structures Engineering (1st ed.). Power and Water University of Technology Press.

[11] Sadeghi, K. (1989). Design and Analysis of Marine Structures (1st ed.). K. N. Toosi University of Technology Press.

[12] Salameh, R., \& Chedid, R. (2020). Economic and geopolitical implications of natural gas export from the East Mediterranean: The case of Lebanon. Energy Policy, 140, 111369. https://doi.org/10.1016/j.enpol.2020.111369

[13] Skiple, C., Anderson, E., \& Fürstenau, J. (2012). Seismic interpretation and attribute analysis of the Herodotus and the Levantine Basin, offshore Cyprus and Lebanon. Petroleum Geoscience, 18(4), 433-442. https://doi.org/10.1144/petgeo2011-072

[14] Total Press Release (2020). Total in Lebanon, Exploration and Production. Total Liban.

https://www.total-liban.com/en/who-we-are/totallebanon/exploration-and-production

[15] U.S. Energy Information Administration (2013), Overview of Oil and natural gas in the Eastern Mediterranean region.

https://www.eia.gov/international/content/analysis/reg ions_of_interest/Eastern_Mediterranean/easternmediterranean.pdf 